\title{
Monsters Take to the Streets! Monstrous Street-Art as Pedagogy of Resistance to Post-Olympic Regeneration in Hackney Wick?
}

\author{
Rhiannon Firth
}

\begin{abstract}
This chapter explores geographies of gentrification and resistance in relation to the monstrous through the lens of street-art in post-Olympic London. It takes as a geographic case study Hackney Wick, which has for a long time been a bastion of alternative and creative living due to cheap rents in large, ex-industrial warehouse spaces. The artistic sociality of the area is imbued within its landscape, as prolific street artists have adorned ex-industrial warehouses and canal-side walls with graffiti and murals. Since the announcement of the 2012 Olympic Games, the area has been a site of intense political and aesthetic contestation. The post-Olympic legacy means that the area has been earmarked for redevelopment, with current residents facing the possibility of joining thousands already displaced by the games. The anxiety of dispossession is reflected by monstrous characters and sinister disembodied teeth, eyes and fingers embedded within the landscape, painted by local artists. Using geographically sensitive mobile and visual methodology to document the landscape and artwork, the chapter analyses and interprets the monstrous themes using a range of theorists including Mikhail Bakhtin, Georges Bataille and Nick Land. I argue that monstrous street-art lays visible claim to public territory for aesthetic purposes at odds with the visions of redevelopers and the needs of capital. Whilst street-art and graffiti do not fit easily within frameworks of organized political resistance or collective social movements, they operate as a kind of epistemological transgression that triggers transformative affects in the viewer. This creates conditions for pedagogies of resistance to gentrification by expressing and mobilizing political affects such as anger and anxiety, raising awareness of geographical politics, and encouraging the viewer to question the status quo of the built environment.
\end{abstract}

Key Words: Gentrification, resistance, street art, graffiti, monstrous, situationist methods, Bakhtin, Bataille, Nick Land, Hackney Wick.

\section{Introduction}

$* * * * *$

I was drawn to the conference: 'Monstrous Geographies: Places and Spaces of Monstrosity', from which this chapter results, because the title offered a lens through which to think about something that had been lurking in the shadows of my consciousness for some time whilst walking through my neighbourhood, Hackney Wick and Fish Island. These are two adjacent areas of London drawn together in the context of the post-Olympic Games redevelopment legacy. They have rich industrial histories dating back to around 1860 and a rich architecture of beautiful old warehouses. The area has been dedicated to light industry for the last 40 years, and 
more recently artists and creative professionals have been re-purposing old industrial infrastructure. In the context of the Olympic Games legacy, the area is undergoing intense 'gentrification', with large plots of land and old warehouses being sold off to developers and existing residents being priced out of the market.

What brought the area to mind in the context of 'Monstrous Geographies' was another aspect of the changing landscape: the words and images that appear on the walls one day, to be viewed, experienced and admired or detested by passers-by, then painted over with something different another day. I live in the area, and these are the monsters with which I have the most intimate relationship and day-to-day contact. In this chapter, I would like to explore their transgressive potential, conceptualizing these monsters as an irruption of the unconscious into the built environment, a carnivalesque underworld - what Bakhtin terms the 'material bodily stratum' ${ }^{1}$ that expresses and produces affects and triggers a pedagogical function that transforms the consciousness of the viewer.

\section{Street-Art: Transgression and Complicity}

Street-art is a form of illicit or illegal drawing in public space. It is distinct from graffiti, yet the boundaries are blurred and the histories intertwined. ${ }^{2}$ Jeff Ferrell argues that 'anarchic' citizens such as street-artists articulate desires and possibilities beyond the needs of private capital, raising questions of legitimate property rights and aesthetic value whilst reassembling public space and community. ${ }^{3}$ Nonetheless, it would be erroneous to view street-art as solely a transgressive or resistant practice. It is simultaneously a 'subcultural activity' and a 'mainstream indicator of "urban cool." "4 Street-art can be an integral part of the process of regeneration, creating an atmosphere of creativity and vibrancy that is later drawn upon by planning authorities and developers to make an area seem appealing. ${ }^{5}$ This may or may not be congruent with the desires of the artists. ${ }^{6}$ In the context of Hackney Wick, Iain Sinclair suggests that many of the artists hail from the nexus of the squatting and warehouse community that gentrification looks liable to displace, which would suggest that gentrification is not in the interests of (some) artists. ${ }^{7}$ Street-art is an area where motives and intentions are hard to discern, unethical to impute, and potentially as multiple as the individuals who choose to communicate in public space. Furthermore, motives are potentially irrelevant since artists cannot impose or elicit singular meanings from their viewers. ${ }^{8}$ The purpose of this chapter is not to speculate on motives, but rather to sketch an affective landscape, resisting interpretive closure whilst engaging with spatial multiplicity and epistemological transgression. Street-art has a tendency to raise extreme emotions in viewers, bringing the imaginal or unconscious into material space, questioning physical and psychic boundaries. The chapter speaks to a growing body of geographic literature calling for a move away from dispassionate, Cartesian observations as the basis for understanding visual culture and a move towards embodied accounts. ${ }^{9}$ 


\section{Monsters and Transgression}

My starting point is the uncanny resonance between the functions of street-art and monstrosity. They have similar epistemological and pedagogical functions: looking beyond the given, transgressing fixed knowledge, questioning boundaries and raising ethico-political questions. Jeffrey Jerome Cohen suggests that we 'read cultures from the monsters they engender'. ${ }^{10}$ Where street-art exists at the intersection of 'subculture' and 'mainstream', monsters also have a tendency to exist simultaneously 'outside' and 'inside'. ${ }^{11}$ Theorists of the monstrous articulate it as the uncanny that resides in the unconscious as an aspect of the repressed subject. ${ }^{12}$ It is the Real, the unknowable, the shadow, the Other. ${ }^{13}$ However, some texts also play with the possibility that it can also signify a more affirmative transgression escape, queering, ${ }^{14}$ the breakdown of boundaries and oppressive categories ${ }^{15}$ and inbetweenness, difference and social rebellion. ${ }^{16}$ Like street-art, monsters may not be explicitly or intentionally political, yet they transgress taken-for-granted assumptions and in so doing open up possibilities by creating new affects.

In theorizing the transgressive function of monstrous street-art, I draw particularly on the works of Bakhtin, Bataille and Nick Land who all elaborate understandings of the monstrous as transformative of consciousness in a way that transgresses the divide between aesthetics and politics. All three theorists begin from an approach that is critical of homogeneity imposed by capitalism, which is viewed as a psychic repression of the affective force of terror and death. ${ }^{17}$ The monstrous also has a utopian aspect. It produces an excess: there is a form of resistance to be found in unconventional, monstrous, grotesque bodies and what these have to say on the themes of death, transgression, hybridity and heterogeneity. The monstrous is notorious for its capacity to unsettle. Tied to Freud's notion of the 'Uncanny', it has the capacity to 'generate material of uncertain epistemological status'. ${ }^{18}$ Using monstrous imagery designed to provoke affects such as eroticism and disgust, the theorists transgress the fundamental limit between life and death ${ }^{19}$ and collapse boundaries between bodies by exploring the transgression of presumed binaries such as human/animal, ${ }^{20}$ human/nature, ${ }^{21}$ desire/disgust, ${ }^{22}$ animate/inanimate, ${ }^{23}$ macrocosm/microcosm, ${ }^{24} \quad$ individual/social, ${ }^{25}$ hierarchy/becoming, ${ }^{26}$ wisdom/madness, ${ }^{27}$ upper/lower body or mouth/anus. ${ }^{28}$ The theme of transgression has been elaborated by feminist and queer theorists who have drawn attention to the importance of transgressing gender, class and social norms including inside/outside, female/male, foreign/native, proletarian/aristocrat. $^{29}$

Articulating these transgressions by means of language and aesthetics of the monstrous creates a pedagogy that is both uncomfortable and comic, and expresses what Bakhtin terms the 'struggle against cosmic terror ... an obscure memory of cosmic perturbations in the distant past and the dim terror of future catastrophes form the very basis of human thought, speech and images ${ }^{30}$ Hierarchical systems can seize on this affective terror for political purposes: 'It is used by all religious systems to oppress man and his consciousness'. ${ }^{31}$ Monstrous aesthetics have a pedagogical 
function because the grotesque image of the body portrayed in monstrous images and culture 'transforms cosmic terror into a gay carnival monster' 32 whereby 'Terror is conquered by laughter'. ${ }^{33}$ This shift of perspective allows one to approach alienating phenomena on the 'plane of material sensual experience'. ${ }^{34}$

\section{Methodology}

My assumption is that street-art constitutes a conversation in the public sphere, ${ }^{35}$ not always intelligible at a rational level yet with potentially transformative effects on viewers at an affective level. ${ }^{36}$ 'Affect' is an aspect of radical pedagogy drawn from Deleuzian theory. ${ }^{37}$ It has been taken up by anarchists ${ }^{38}$ and poststructuralists $^{39}$ and resonates with themes in situationist and psychogeographic literatures. ${ }^{40}$ Affect refers to an intensity of experience that exceeds individualized emotions and feelings, drawing attention to the ways in which desire flows through and changes multiplicities including peoples, groups and the built environment. ${ }^{41}$ This approach treats the pedagogical moment as becoming-other, a transgression, rather than imbuing fixed knowledge within a fixed being, cultivating awareness of multiple perspectives on processes of alienation so as to open one's own perception to the perspectives of others. ${ }^{42}$ Inspired by the situationists and their concepts of dérive and détournement, Alexander Bridger contends that it is possible to dissociate oneself from one's conventional, everyday understandings of the urban environment and reach a kind of critical consciousness as to how the environment is both shaped by social conditions and indeed helps to shape those everyday experiences and understandings that it is normally hard to step outside. ${ }^{43}$ Similarly, my data collection combined the practice of critical walking with autoethnographic notes and photographs, offering a narrative account interspersed with photographs in dialogue with the theorists of transgression. Having read the texts prior to my walk, I re-read the theorists through and with the landscape in Hackney Wick.

\section{An Affective Cartography}

I undertook three dice walks of around an hour each. I decided on the rules beforehand; that is, the direction that each number would signify at different types of crossing. I also decided on the boundaries of the area that I would stay within. This included Hackney Wick and Fish Island, the boundaries of which are easy to identify both on a map and within the territory because they form a triangle with the A12 road on two sides, and the Lee Navigation Canal on another side. I took notes and photographs as I walked and consulted the texts. What follows are a very limited number of examples from a larger pool of data, due to the restraints of the word limit for the chapter. 


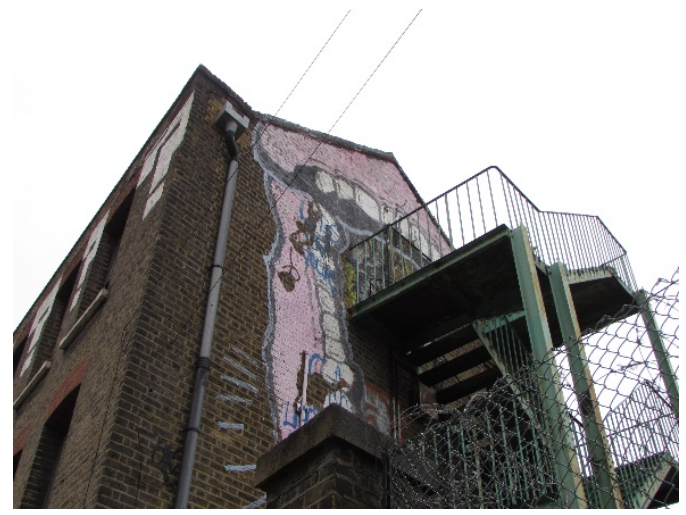

Image 1: Street-art around fire escape on Smeed Road warehouse. Photograph (C) 2015. Rhiannon Firth. Used with permission.

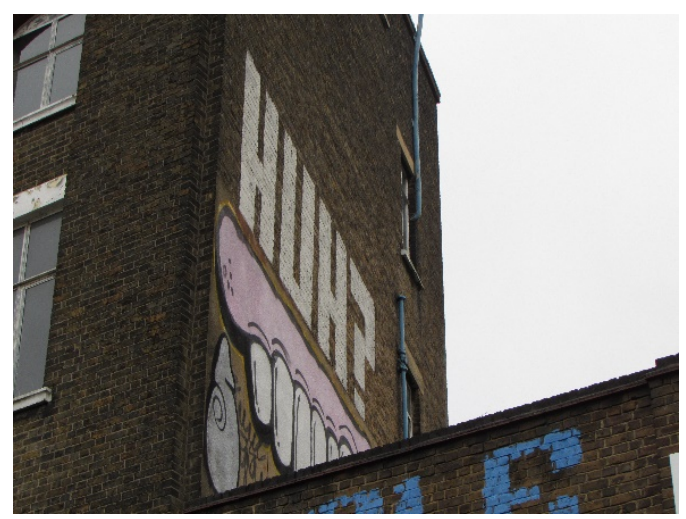

From Dice Walk \#1: Images showing the stereotypical pink gums and teeth of the artist Sweet Toof. ${ }^{44}$ Disembodied teeth seem transgressive because they return us to 'partial objects', deconstructing the unity of the self and returning us to the material bodily stratum through emphasis on the body. ${ }^{45}$ They give living form to the buildings, turning inert matter into organic mouths, and transgress self/other relations, drawing the buildings closer to human experience, suspending alienation. ${ }^{46}$

Disembodied teeth and gums transgress certain binaries: life/death, body/world. For Bakhtin, 'gaping jaws', teeth and the mouth represent the entrance to the body, 
showing that it is open to the world and to others, rather than closed and individualised. ${ }^{47}$ Land frequently links death to its ability to 'bite' and it is stated that death has 'teeth'. ${ }^{48}$ For Bataille, the mouth is primitive and animalistic, representing the affective and pre-rational aspects of the human, expressing both rage and terror. ${ }^{49}$ I wonder: are these teeth trying to express rage, or terror? Do they say 'We are frightened' or 'we are frightening'? Perhaps they are transgressing individualized emotions in this sense, and suspending the alienation presumed between that which is frightened and that which is frightening, expressing a conception of affect laid out on 'one plane of material sensual experience' ${ }^{50}$ and transgressing the limits separating the body from the world. ${ }^{51}$ Might this provoke to a feeling of empathy and connectedness with the built environment? The methodology used in this chapter raises more questions than answers, in the same way that the images might create 'openness', in the Bakhtinian sense, to otherness.

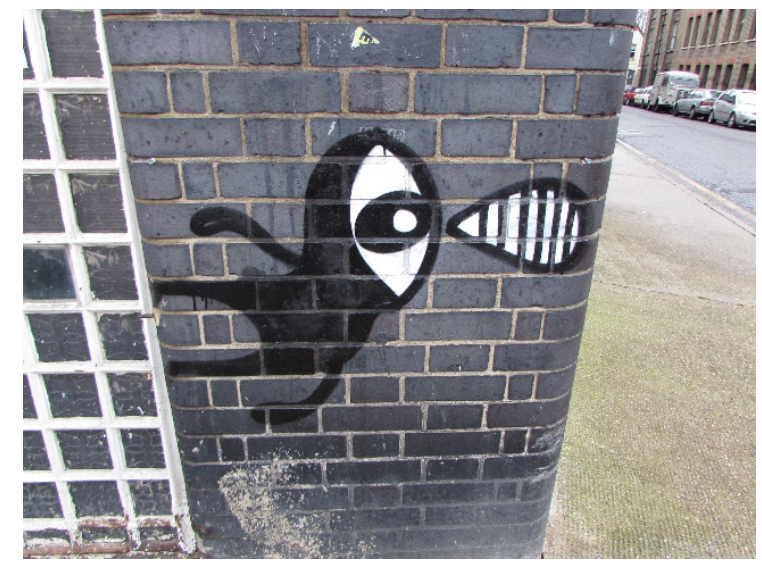

Image 3: Street-art on junction of Smeed Road and Stour Road. Photograph (C) 2015. Rhiannon Firth. Used with permission.

From Dice Walk \#1: The image looks somewhat like a baby with one eye, perhaps a rather cute Cyclops, it makes me feel a combination of innocence, intrigue, fear and horror. Nick Land quotes Nietzsche: 'Only your eye - monstrously/ stares at me infinitely'. ${ }^{52}$ Bataille views the eye as 'extreme seductiveness at the boundary of horror' 53 and as symbolic of consciousness. It is positioned as a 'third eye' or Pineal Eye, on which Bataille also writes as being connected to the attainment of excess through a primordial relationship to nature. ${ }^{54}$ Bakhtin recounts how Rabelais loved 'free play with the human body' including 'cyclopes with one eye on the forehead, others with eyes on shoulders or their backs'. ${ }^{55}$ The eye is an opening to the body. It receives information and produces a viewpoint or perspective. Like other 
monstrous characters, the Cyclops emphasizes the ways in which 'its exterior aspect is not distinct from the inside, and the exchange between the body and the world is emphasized'. ${ }^{56}$ Perhaps the Cyclops has something to say about the ways in which humans are formed by their environment, and the importance of maintaining connectedness.

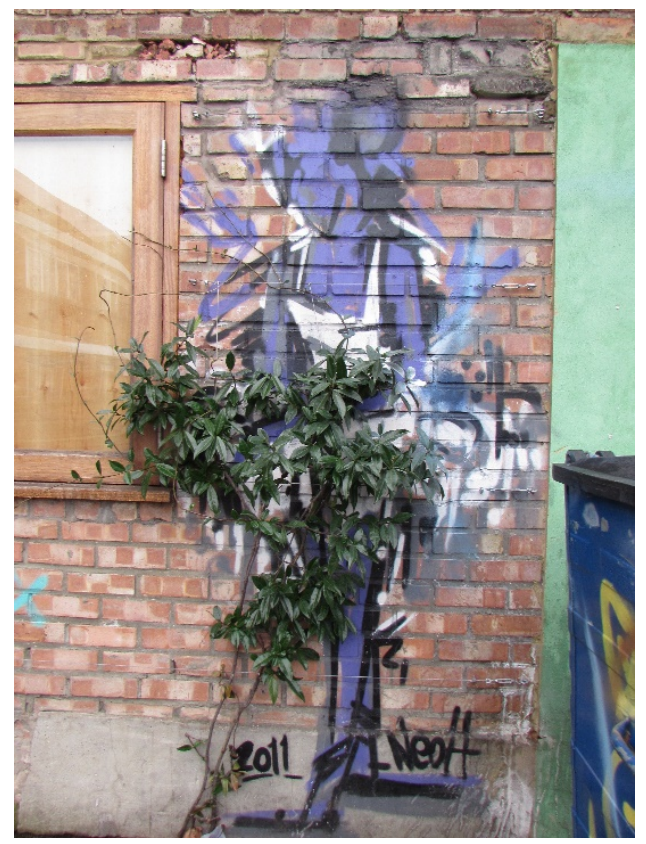

Image 4: Street-art outside Stour Space. Photograph (C) 2015. Rhiannon Firth. Used with permission.

From Dice Walk \#1: This image, which is outside the Counter Café and gallery Stour Space seems to be a female figure, perhaps with a mouse ear, with a climbing plant strategically placed over the pubic region; reminiscent of themes surrounding the transgression of human/animal, human/nature and self/other. Deleuze and Guattari place great emphasis on the importance of becoming-other, for example becoming-animal as a form of resistance and transgression. ${ }^{57}$ Bakhtin also imagines a form of human-animal relations in terms of becoming. ${ }^{58}$ Becoming resists hierarchy and alienation, because a hierarchy can 'determine only that which represents stable, immovable, and unchangeable being, not free becoming'. ${ }^{59}$ 


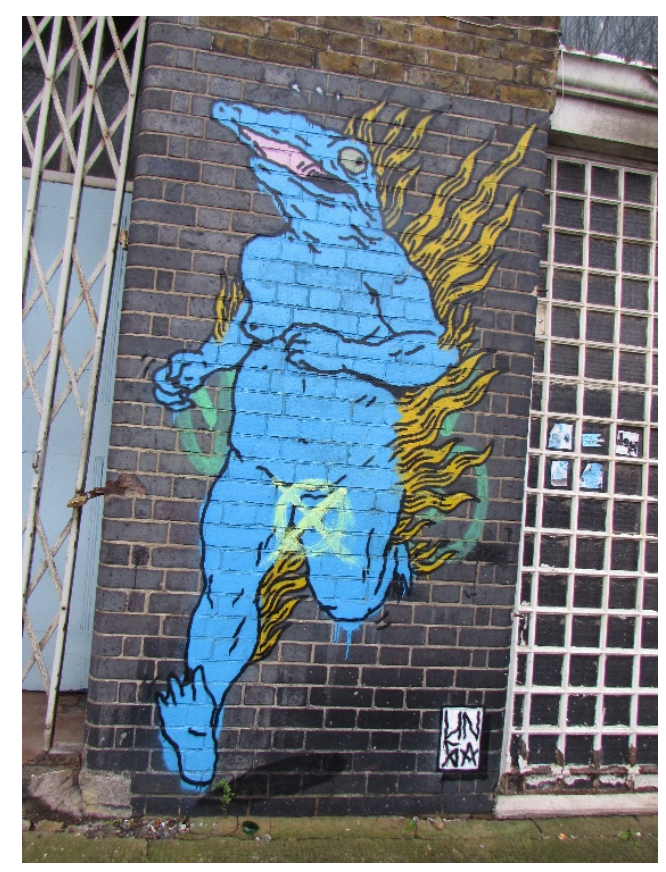

Image 5: Street-art on Stour Road. Photograph (C) 2015. Rhiannon Firth. Used with permission.

From Dice walk \#1: This seems to be a reptile or dinosaur running on two legs and with a body like a human, again echoing themes surrounding human/animal hybridity and transgression. He returns us to the material bodily stratum because he's expressing a clear affect, possibly fear, and is running from the fire that he cannot escape, reminiscent of 'cosmic terror' discussed above, yet like Bakhtin's grotesque images, he is a comic character, with a flabby blue physique.

From Dice walk \#2: The skeletons are monstrous, and transgressive because they are the living dead; they transgress the life/death binary. Their placing on an erstwhile advertising billboard is ominous. For Nick Land, Capitalism is founded on an Enlightenment rationality where death is hidden from view, and prevented from 'injecting a transcendent reference into production, and ensuring superterrestrial interests their rights' ${ }^{60}$ People continue to defer pleasure and gratification because they are not aware of their own mortality. A reading of this mural as critical or radical might posit the skeletons as a metaphor for capitalism, masculinity or modernity, showing the domination of the forces of death over life in capitalism: 'Compared to the immortal soul of capital, the death of the individual becomes an empirical triviality, a mere re-allocation of stock'. ${ }^{61}$ Nonetheless, this particular image makes 
me feel uncomfortable because of the gender positionality and objectification of the women.

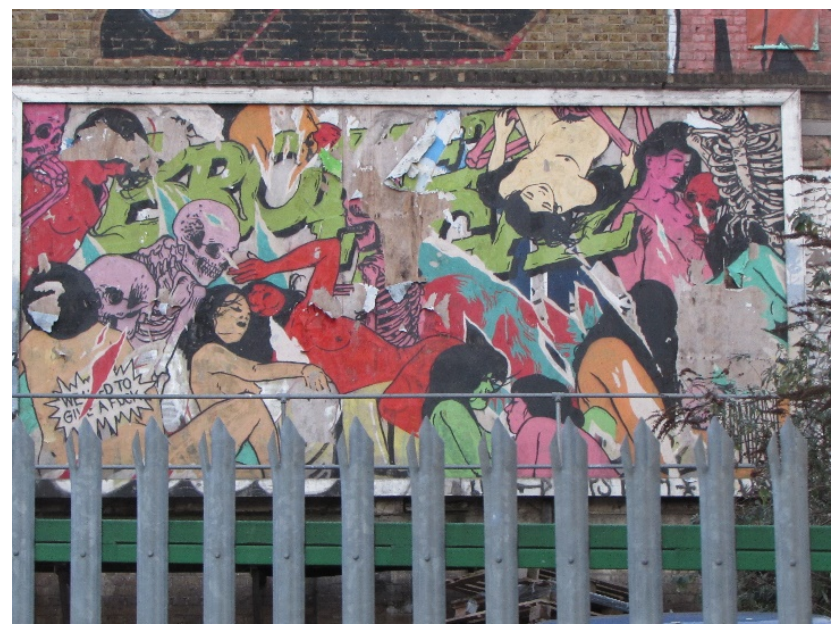

Image 6: Street-art on Billboard on White Post Lane. Photograph (C) 2015. Rhiannon Firth. Used with permission.

\section{Conclusion}

Monstrous street art reminds us of death as an imminent (and immanent) threat rather than something 'toothless' that can be rationalized or reasoned away through transcendental theism: "The death "proper" to matter is the jagged edge of its impropriety, its teeth'. ${ }^{62}$ The images transgress habitual thinking about binaries between living and inert matter, the animate and inanimate, as well as portraying body-horror and death directly. The monstrous, disembodied body parts and deathly figures of the street-art in Hackney Wick give rise to anxious affects, reminding us of our own mortality in a time where usually 'death is privatized, withdrawn into interiority, to flicker at the edge of the contract as a narcissistic anxiety without public accreditation' ${ }^{63}$ Revelation of death and mortality highlights alienation. ${ }^{64}$ However, the monsters also have a utopian aspect, inviting us to imagine a world with different boundaries, differently conceived relations with nature and between Self and Other. Drawing on the theorists, and my personal affective responses to the images, I would like to posit the idea of a pedagogical cartography, which articulates the affective potential of the landscape. As a methodology, psychogeographical wanderings are flawed in some respects. In particular, it presents a very individualized and personal perspective. Nonetheless, working with affect and embodiment is important, because these are essential aspects of everyday life for all humans ${ }^{65}$ and have frequently been neglected in much critical and political theory. ${ }^{66}$ 
The images open up questions about what it means to be human, whilst producing affects that may be either comforting or unsettling yet produce a dis-alienating, creative relationship to the built environment. Street-art takes the walls of run-down areas as a basis to form a 'transgressive utopia'; a term coined by Lucy Sargisson to refer to bodies of thought and bodies of people living together in intentional communities. She argues that these illustrate the possibility of 'other' ways of living, and 're-inscribe alternative relations onto the culture that we inhabit' ${ }^{67}$ by transgressing fixed knowledge and assumptions regarding, for example, public/private property and Self/Other Relations. As such, transgressive utopias offer an important resource for political thought, and as I have argued elsewhere, for pedagogical thought. ${ }^{68}$ In this chapter I have shown some of the ways in which monstrous street-art has a transgressive function at an epistemological level, in particular transgressing concepts such as Self/Other, Life/Death, Human/Animal, Culture/Nature: 'Guerrilla artists, whatever their motives, collaborate with the architecture of ruin. Living arms and hands intertwine with bindweed and yarrow. Pink-gummed mouths grin on concrete stumps'. ${ }^{69}$ Bringing the landscape to life arguably adds to its value, rendering it animate, and worth protecting. Furthermore, one could argue for a political function: in a world where space is becoming increasingly privatized, these conversations on the walls of the changing landscape might be seen as a way of opening up public space. Nonetheless, these practices fall far short of organized political resistance, and as noted previously in this chapter, street-art is often a precursor, whether intentional or not, to the gentrification process. There is no doubt that monstrous street-art articulates transgressive desires, both through the process (which may involve illegal activity and trespass) and through aesthetics. The transgressive potential of monstrous street-art lies in its ambiguity, and its ability to transgress set assumptions, expectations and knowledge at an epistemological level by creating space for audiences to be affectively challenged through encounters with diversity and difference within the urban environment. I would like to conclude with an open-ended suggestion as an area for further study, the relationship between epistemological-aesthetic transgression and political resistance in the context of gentrifying geographical change.

\section{Notes}

${ }^{1}$ Mikhail Bakhtin, Rabelais and His World, trans. Hélène Iswolsky (Bloomington: Indiana University Press, 1984), 370.

${ }^{2}$ Alison Young, Street Art, Public City: Law, Crime and the Urban Imagination (Abingdon: Routledge, 2014), 1. See also Orestis Pangalos, 'Testimonies and Appraisals on Athens Graffiti, Before and After the Crisis', Remapping Athens: A Guide to Athens, eds. Myrto Tsilimpounidi and Aylwyn Walsh (Alresford: Zero Books, 2014), 154-176. 
${ }^{3}$ Jeff Ferrell, Tearing Down the Streets: Adventures in Urban Anarchy (Basingstoke: Palgrave, 2001), 246

${ }^{4}$ Young, Street Art, Public City, 2.

${ }^{5}$ BAVO, 'Plea for an Uncreative City', BAVO Research, August 31, 2006, Viewed on 27 March 2015, http://www.bavo.biz/texts/view/156.

${ }^{6}$ Andrew Harris, 'Art and Gentrification: Pursuing the Urban Pastoral in Hoxton, London', Transactions of the Institute of British Geographers 37 (2011): 226-241, 234.

${ }^{7}$ Iain Sinclair, Ghost Milk: Calling Time on the Grand Project (London: Penguin Books, 2011), 73.

${ }^{8}$ Nick Schuermans, Maarten Loopmans and Joke Vandenabeele, 'Public Space, Public Art and Public Pedagogy', Social \& Cultural Geography 13.7 (2012): 675682.

9 Harriet Hawkins, "“The Argument of the Eye"? The Cultural Geographies of Installation Art', Cultural Geographies 17.3 (2010): 321-340. See also Alexander Bridger, 'Psychogeography and the Study of Social Environments: Extending Visual Research in Psychology', Visual Methods in Psychology: Using and Interpreting Images in Qualitative Research, ed. Paula Reavey (Sussex: Psychology Press, 2011), 284-295; Alexander Bridger, 'Psychogeography and Feminist Methodology', Feminism \& Psychology 23.3 (2013): 285-298.

10 Jeffrey Jerome Cohen, 'Monster Culture (Seven Theses)', Monster Theory: Reading Culture, ed. Jeffrey Jerome Cohen (Minneapolis: University of Minnesota Press, 1996): 3-25, 3.

11 Tyson E. Lewis and Richard Kahn, Education Out of Bounds: Reimagining Cultural Studies for a Posthuman Age (New York: Palgrave Macmillan, 2010), 2.

${ }^{12}$ Sigmund Freud, The Uncanny (London: Penguin Books, 2003). See also Hélène Cixous, 'Fiction and Its Phantoms: A Reading of Freud's Das Unheimliche (The Uncanny)', New Literary History 7.3 (1976): 525-548.

${ }^{13}$ Margrit Shildrick, Embodying the Monster: Encounters with the Vulnerable Self (London: Sage Publications, 2002).

14 Judith Halberstam, Skin Shows (Durham and London: Duke University Press, 1995).

${ }^{15}$ Lewis and Kahn, Education Out of Bounds, 2.

${ }^{16}$ Bakhtin, Rabelais and His World. See also Georges Bataille Visions of Excess: Selected Writings 1927-1939, trans. and ed. Allan Stoekl (Manchester: Manchester University Press, 1985).

${ }^{17}$ Nick Land, The Thirst for Annihilation: Georges Bataille and Virulent Nihilism (An Essay in Atheistic Religion) (London and New York: Routledge, 1992), 112; Bakhtin, Rabelais and His World, 335-339; Georges Bataille, The Bataille Reader, eds. Fred Botting and Scott Wilson (Oxford: Blackwell, 1997), 81.

${ }^{18}$ Hugh Haughton, 'Introduction' to The Uncanny, by Sigmund Freud (London: Penguin Books, 2003): i-lv, xlvii. 
${ }^{19}$ Bataille, The Bataille Reader, 42; Bakhtin, Rabelais and His World, 322, 352; Land, The Thirst for Annihilation, 111-112.

${ }^{20}$ Land, The Thirst for Annihilation, 175-202.

${ }^{21}$ Bakhtin, Rabelais and His World, 328.

${ }^{22}$ Bataille, The Bataille Reader, 253; Bakhtin, Rabelais and His World, 305.

${ }^{23}$ Bakhtin, Rabelais and His World, 365.

${ }^{24}$ Bakhtin, Rabelais and His World, 361; Nick Land, Fanged Noumena: Collected Writings 1987-2007, eds. Robin MacKay and Ray Brassier (Falmouth: Urbanomic, 2011), 269.

${ }^{25}$ Bakhtin, Rabelais and His World, 321.

${ }^{26}$ Ibid., 364.

${ }^{27}$ Ibid., 361.

${ }^{28}$ Bataille, Visions of Excess, 88; Bakhtin, Rabelais and His World, 323.

${ }^{29}$ Halberstam, Skin Shows, 1.

${ }^{30}$ Bakhtin, Rabelais and His World, 335.

${ }^{31}$ Ibid., 335.

${ }^{32}$ Ibid., 335.

${ }^{33}$ Ibid., 336.

${ }^{34}$ Ibid., 381.

${ }^{35}$ Ferrell, Tearing Down the Streets, 192.

${ }^{36}$ Alison Young, 'Criminal Images: The Affective Judgment of Graffiti and Street Art', Crime, Media, Culture 8 (2012): 297-314.

${ }^{37}$ Gilles Deleuze and Félix Guattari, A Thousand Plateaus (London: Continuum, 1988), 265.

${ }^{38}$ Paul Routledge, 'Toward a Relational Ethics of Struggle: Embodiment, Affinity, and Affect', Contemporary Anarchist Studies, eds. Randall Amster, Abraham DeLeon, Luis A. Fernandez, Anthony J. Nocella II and Deric Shannon (Oxford: Routledge, 2009), 82-92.

39 Nigel Thrift, 'Intensities of Feeling: Towards a Spatial Politics of Affect', Geografiska Annaler B 86 (2004): 57-78; Michalinos Zembylas, 'Risks and Pleasures: A Deleuzo-Guattarian Pedagogy of Desire in Education', British Educational Research Journal 33.3 (2007): 331-347; Sarah Amsler, 'From "Therapeutic" to Political Education: The Centrality of Affective Sensibility in Critical Pedagogy', Critical Studies in Education 52.1 (2011): 47-63.

${ }^{40}$ David Pinder, 'Subverting Cartography: The Situationists and Maps of the City', Environment and Planning A 28.3 (1996): 405-427, 415.

41 Alejandro de Acosta, 'Two Undecidable Questions for Thinking in which Anything Goes', Contemporary Anarchist Studies, eds. Randall Amster, Abraham DeLeon, Luis A. Fernandez, Anthony J. Nocella II and Deric Shannon (Oxford: Routledge, 2009): 26-43, 28; Thrift, 'Intensities of Feeling', 60.

${ }^{42}$ Megan Boler, Feeling Power: Emotions and Education (New York: Routledge, 1999): 185; Sara C. Motta, 'Teaching Global and Social Justice as Transgressive 
Spaces of Possibility', Antipode 45.1 (2013): 80-100; Michalinos Zembylas, 'Witnessing in the Classroom: The Ethics and Politics of Affect', Educational Theory 56.3 (2006): 305-324.

${ }^{43}$ Bridger, 'Psychogeography and the Study of Social Environments'; Bridger, 'Psychogeography and Feminist Methodology', 286.

${ }^{44}$ It is beyond the scope of this research to determine the authenticity of public streetart. Works by the artist Sweet Toof can be found on the website: Sweet Toof, Official Website, 2012, Viewed on 27 March 2015, http://sweettoof.com.

${ }^{45}$ Bakhtin, Rabelais and His World, 370.

${ }^{46}$ Ibid., 381.

${ }^{47}$ Ibid., 338-339.

${ }^{48}$ Land, The Thirst for Annihilation, 111.

${ }^{49}$ Bataille, Visions of Excess, 59-60.

${ }^{50}$ Bakhtin, Rabelais and His World, 381.

${ }^{51}$ Ibid., 347.

${ }^{52}$ Nietzsche, The Gay Science, section 371, quoted in Land, Fanged Noumena, 228.

${ }^{53}$ Bataille, The Bataille Reader, 17.

${ }^{54}$ Bataille, Visions of Excess, 82.

${ }^{55}$ Bakhtin, Rabelais and His World, 345.

${ }^{56}$ Ibid., 355.

${ }^{57}$ Deleuze and Guattari, A Thousand Plateaus, 269-270.

${ }^{58}$ Bakhtin, Rabelais and His World, 364.

${ }^{59}$ Ibid., 364.

${ }^{60}$ Land, The Thirst for Annihilation, 111.

${ }^{61}$ Ibid.

${ }^{62}$ Ibid.

${ }^{63}$ Ibid.

${ }^{64}$ Bataille, The Bataille Reader, 242-245.

${ }^{65}$ Henri Lefebvre, The Critique of Everyday Life (London: Verso, 2014).

${ }^{66}$ Bridger, 'Psychogeography and Feminist Methodology', 285.

${ }^{67}$ Lucy Sargisson, Utopian Bodies and the Politics of Transgression (London: Routledge, 2000), 116.

${ }^{68}$ Rhiannon Firth, 'Toward a Critical Utopian and Pedagogical Methodology', Review of Education, Pedagogy and Cultural Studies 35.4 (2013): 256-276.

${ }^{69}$ Sinclair, Ghost Milk, 120-121.

\section{Bibliography}

Amsler, Sarah. "From "Therapeutic" to Political Education: The Centrality of Affective Sensibility in Critical Pedagogy'. Critical Studies in Education 52.1 (2011): 47-63. 
Bakhtin, Mikhail. Rabelais and His World. Translated by Hélène Iswolsky. Bloomington: Indiana University Press, 1984.

Bataille, Georges. The Bataille Reader, edited by Fred Botting and Scott Wilson. Oxford: Blackwell, 1997.

Bataille, Georges. Visions of Excess: Selected Writings 1927-1939. Translated and edited by Allan Stoekl. Manchester: Manchester University Press, 1985.

BAVO. 'Plea for an Uncreative City'. BAVO Research, August 31, 2006. Viewed on 27 March 2015. http://www.bavo.biz/texts/view/156.

Boler, Megan. Feeling Power: Emotions and Education. New York: Routledge, 1999.

Bridger, Alexander. 'Psychogeography and Feminist Methodology'. Feminism \& Psychology 23.3 (2013): 285-298.

Bridger, Alexander. 'Psychogeography and the Study of Social Environments: Extending Visual Research in Psychology'. Visual Methods in Psychology: Using and Interpreting Images in Qualitative Research, edited by Paula Reavey, 284-295. Sussex: Psychology Press, 2011.

Cixous, Hélène. 'Fiction and Its Phantoms: A Reading of Freud's Das Unheimliche (The Uncanny)'. New Literary History 7.3 (1976): 525-548.

Cohen, Jeffrey Jerome. 'Monster Culture (Seven Theses)'. Monster Theory: Reading Culture, edited by Jeffrey Jerome Cohen, 3-25. Minneapolis: University of Minnesota Press, 1996.

de Acosta, Alejandro. 'Two Undecidable Questions for Thinking in which Anything Goes'. Contemporary Anarchist Studies, edited by Randall Amster, Abraham DeLeon, Luis A. Fernandez, Anthony J. Nocella II and Deric Shannon, 26-43. Oxford: Routledge, 2009.

Deleuze, Gilles and Félix Guattari. A Thousand Plateaus. London: Continuum, 1988.

Ferrell, Jeff. Tearing Down the Streets: Adventures in Urban Anarchy. Basingstoke: Palgrave, 2001.

Freud, Sigmund. The Uncanny. London: Penguin Books, 2003. 
Halberstam, Judith. Skin Shows. Durham, NC. and London: Duke University Press, 1995.

Harris, Andrew. 'Art and Gentrification: Pursuing the Urban Pastoral in Hoxton, London'. Transactions of the Institute of British Geographers 37 (2011): 226-241.

Haughton, Hugh. 'Introduction'. The Uncanny by Sigmund Freud, i-lv. London: Penguin Books, 2003.

Hawkins, Harriet. 'The Argument of the Eye? The Cultural Geographies of Installation Art'. Cultural Geographies 17.3 (2010): 321-340.

Land, Nick. Fanged Noumena: Collected Writings 1987-2007, edited by Robin MacKay and Ray Brassier. Falmouth: Urbanomic, 2011.

Land, Nick. The Thirst for Annihilation: Georges Bataille and Virulent Nihilism (An Essay in Atheistic Religion). London and New York: Routledge, 1992.

Lefebvre, Henri. Critique of Everyday Life. London: Verso, 2014.

Lewis, Tyson E. and Richard Kahn. Education Out of Bounds: Reimagining Cultural Studies for a Posthuman Age. New York: Palgrave Macmillan, 2010.

Motta, Sara C. 'Teaching Global and Social Justice as Transgressive Spaces of Possibility’. Antipode 45.1 (2013): 80-100.

Pangalos, Orestis. 'Testimonies and Appraisals on Athens Graffiti, Before and After the Crisis'. Remapping Athens: A Guide to Athens, edited by Myrto Tsilimpounidi and Aylwyn Walsh, 154-176. Alresford: Zero Books, 2014.

Pinder, David. 'Subverting Cartography: The Situationists and Maps of the City'. Environment and Planning A 28.3 (1996): 405-427.

Routledge, Paul. 'Toward a Relational Ethics of Struggle: Embodiment, Affinity, and Affect'. Contemporary Anarchist Studies, edited by Randall Amster, Abraham DeLeon, Luis A. Fernandez, Anthony J. Nocella II and Deric Shannon, 82-92. Oxford: Routledge, 2009.

Schuermans, Nick, Maarten Loopmans and Joke Vandenabeele. 'Public Space, Public Art and Public Pedagogy'. Social \& Cultural Geography 13.7 (2012): 675682. 
Shildrick, Margrit. Embodying the Monster: Encounters with the Vulnerable Self. London: Sage Publications, 2002.

Sinclair, Iain. Ghost Milk: Calling Time on the Grand Project. London: Penguin Books, 2011.

Sweet Toof. Official Website. 2012. Viewed on 27 March 2015. http://sweettoof.com/.

Thrift, Nigel. 'Intensities of Feeling: Towards a Spatial Politics of Affect'. Geografiska Annaler B 86 (2004): 57-78.

Young, Alison. 'Criminal Images: The Affective Judgment of Graffiti and Street Art'. Crime, Media, Culture 8 (2012): 297-314.

Young, Alison. Street Art, Public City: Law, Crime and the Urban Imagination. Abingdon: Routledge, 2014.

Zembylas, Michalinos. 'Risks and Pleasures: A Deleuzo-Guattarian Pedagogy of Desire in Education'. British Educational Research Journal 33.3 (2007): 331-347.

Zembylas, Michalinos. 'Witnessing in the Classroom: The Ethics and Politics of Affect'. Educational Theory 56.3 (2006): 305-324.

Rhiannon Firth is post-doctoral research fellow at Cass School of Education and Communities, University of East London. Her research interests include Utopian theory and practice, social movements and political resistance, and transgressive spatial epistemologies. 